\title{
Assessment of Type 2 Anti-Diabetes on Barringtonia racemosa (L.) Dichloromethane Extract in Streptozotocin (STZ) - Induced Diabetic Rats
}

\section{Umaru IJ ${ }^{1,2 *}$, Umaru $\mathrm{HA}^{3}$ and Umaru $\mathrm{KI}^{4}$}

${ }^{1}$ Faculty of Resource Science and Technology, University of Malaysia Sarawak, Malaysia

2Department of Biochemistry, Federal University, Wukari, Nigeria

${ }^{3}$ Department of Biochemistry Moddibo Adama University of Technology Yola, Nigeria

${ }^{4}$ Department of Biochemistry, University of Maiduguri Borno state, Nigeria

\section{Research article}

Volume 3 Issue 5

Received Date: October 11, 2018

Published Date: November 01, 2018

DOI: $10.23880 / \mathrm{ijbp}-16000141$

*Corresponding author: Isaac John Umaru, Faculty of Resource Science and Technology, University of Malaysia Sarawak, Kota Samarahan, Malaysia, Tel: 168395004; Email: umaruisaac@gmail.com

\section{Abstract}

Objective: Type 2 diabetes mellitus is a heterogeneous group of metabolic disorders characterized by persistent hyperglycaemia. The aim of this research work is to gather scientific information about the possibility to utilize the dichloromethane leaf extract of Barringtonia racemosa as an agent of antidiabetic drug.

Material and Methods: The Crude extract was obtained through serial extract of five solvents, Hexane, dichloromethane, ethyl acetate, chloroform and methanol while the Assessment of type 2 anti-diabetes was conducted on Streptozotocin (STZ) -induced diabetic albino rats and the data were analysed through one-way ANOVA software. Histopathological studies of the pancreas and kidney were made to get evidence of the $\beta$-cell performance and the renal tissue respectively.

Results: The streptozotocin (STZ) induced diabetic rats treated with the Dichloromethane extract experienced an antidiabetic effect and the histopathologic observations showed increasing of the granulated $\beta$-cell at $p<0.001$ ) and no renal tissue damage in the tested rats.

Conclusion: The result of this study revealed that the dichloromethane crude extract of Barringtonia racemosa could be utilized as an agent source of type 2 anti-diabetes.

Keywords: Barringtonia racemosa; Dichloromethane; Streptozotocin; Diabetic; Rats 


\section{International Journal of Biochemistry \& Physiology}

Abbreviations: T2DM: Type II Diabetes Mellitus; WHO: World Health Organization; T1D: Type 1 Diabetic; STZ: Dtreptozotocin.

\section{Introduction}

Type II diabetes mellitus (T2DM) is a fast-growing epidemic affecting people globally. Furthermore, multiple complications and co-occurring with a primary disease are associated with T2diabetes. Lifestyle modifications along with pharmacotherapy and patient education are the main stay of therapy for patients afflicted with T2DM. Western medications are frequently associated with severe adverse drug reactions and high costs of treatment. However, herbal medications have long been used in the treatment and prevention of T2DM in traditional medicine which was presumed to avert this treat of health around the globe. This disorder is a chronic metabolic menace characterized by absolute or relative deficiencies in insulin secretion or insulin action associated with chronic hyperglycaemia and disturbances of carbohydrate, lipid and protein metabolism [1]. The disease is of three types recognized by the World Health Organization (WHO) such as (i) type 1 diabetes (insulindependent) (ii) type 2 diabetes (non-insulin-dependent) and (iii) gestational diabetes. The $\beta$-cells in the pancreas are the key players in this disorder called glycaemic homeostasis. The glucotoxicity, lipotoxicity, inflammatory mediators and incretion were reported to modulate function and survival of $\beta$-cell [2]. Besides, oxidative stress is thought to be a major risk factor on the onset and progression of diabetes [3]. Both type- 1 and type- 2 diabetes are associated with increased formation of free radicals and decreased antioxidant potential [4]. Thus, T2DM accounts for over $90 \%$ of cases globally [5-7]. According to the World Health Organization (WHO), in 2011, approximately 364 million people globally suffer from diabetes (DM), with projections that DM-related deaths will double from 2005 to 2030 [8].

Diabetes being a common disease in the developed and developing countries. According to a WHO report in 2011, approximately 360 million people globally suffer from diabetes. The epidemic is more pronounced in developing countries such as Malaysia, Nigeria respectively because of their feeding habits. As per reports of the WHO, 32 million people of Malaysia had diabetes. The Malaysians would have a total number of 2.48 million diabetics compared to 0.94 million in 2000 that is about $164 \%$ increase. it is expected that more people in Malaysia will be affected by diabetes in the near future [9].

In the study of this diabetes diseases there are several animal models available to test for the mechanisms of diabetic complications, most of the studies on diabetic in animal models are largely restricted to type 1 diabetic (T1D) conditions $[10,11]$. In this context streptozotocin (STZ) [12-14] or alloxan-induced diabetic models are extensively used to study the diabetic among scientist and both these models mimic the T1D in humans. It was reported that oxidative stress appears to be a major factor in the development of other diseases in T1D, along with the activation of polyol pathway and non-enzymatic glycation $[11,12,15]$.

Thus streptozotocin (STZ) induced rat model is one of the most frequently used for T2D-like models [16-18] which mimics human diabetes [19]. Previous studies on this model were found to have characteristics of pancreatic beta-cell destruction followed by beta-cell regeneration and glucose intolerance [20,21]. Subsequently, other authors confirmed these findings and showed that STZ treated rats in adulthood display the typical characteristics of T2D [22,23]. This animal model is mainly used to screen hypoglycaemic or antidiabetic agents [24-26] and also for hypolipidemic and oxidative stress related studies [27]. However, no studies attempted to use this model for investigating the Assessment of Type 2 Anti-Diabetes of Barringtonia racemosa (L.) Dichloromethane extract in streptozotocin (STZ) - Induced Diabetic Rats. Therefore, in this present study we evaluated STZ model for development of an agent for T2D.

Therefore, the choice of Barringtonia racemosa an evergreen mangrove plant, belonging to the family Lecythidaceae to cutely the menace of Diabetic disease is an option. The stem-bark and leaves have been traditionally used for anticancer, analgesic, antibacterial, anticolic and antifungal activities [28-37] this motivated us to study the antidiabetic potential of this plant extract. 


\section{International Journal of Biochemistry \& Physiology}

\begin{tabular}{|c|c|c|}
\hline Part of plant use & Treatment & Reference \\
\hline Leaves & $\begin{array}{l}\text { High blood pressure, itching, chicken pox itch, } \\
\text { rheumatism febrifuge. }\end{array}$ & Kabir et al., 2013, Osman et al., 2015 [35,36] \\
\hline Stem-bark & Fish poison, insecticide, skin disease, & Lim, 2012 [37]. \\
\hline Roots & Deobstruent, Relief in stomach ache & $\begin{array}{l}\text { Isaac et al., 2018, Giesen et al., 2007, } \\
\text { Manjunah 1948 [38-40]. }\end{array}$ \\
\hline Seeds & Tumors, fish poison, colic, febrifuge, vermufuge & Jayaweera et al., 1981[41]. \\
\hline Fruits & $\begin{array}{l}\text { Poison wild pig, cough, asthma, diarrhea, eczema. } \\
\text { Hemicrania, ophthalmia, cough, asthma, diarrhea }\end{array}$ & \begin{tabular}{|c|}
$\begin{array}{c}\text { Thomas et al., 2002, Manjunah et al., 1948, } \\
\text { Jayaweera et al., 1981, Giesen et al., 2007, } \\
\text { Nadkami 1976.[34,40,41,39,42] }\end{array}$ \\
\end{tabular} \\
\hline Part of plant (Antioxidant) & Secondary Metabolites & \\
\hline Leaves & Terpenoid, & Behbahani et al., 2007 [43] \\
\hline Leaves, stem-bark & Flavonoid, Phenolic and phenolic acid & Kong et al., 2014 [44] \\
\hline Fruits & Phenolic acid & Sulaiman and Ooni, 2014 [45] \\
\hline \multicolumn{3}{|c|}{ (Antibacterial) } \\
\hline Leaves & Mycobacterium smegmatic & Mmushi et al. (2010) [46] \\
\hline \multirow{3}{*}{ Stem-bark } & Staphylococcus aureus, Staphylococcus epidermidis & Saha et al., 2013 [47] \\
\hline & Eschericia coli, Shigella dysentriae, & \\
\hline & Vibrio cholerae, Proteus sp. & \\
\hline Roots & Bacillus cereus, Salmonella typhy & Khan et al., 2001. [33] \\
\hline (Antifungal) & Antimycobacterial Mycobacterium smegmatic & Mmushi et al. (2010). [46] \\
\hline \multicolumn{3}{|l|}{ Leaves } \\
\hline \multirow{5}{*}{ Leaves, stem-bark } & Antifungus Fusarium sp., Tricoderma koningii, & Hussin et al. (2009). [48] \\
\hline & Penicillium sp., Ganoderma tropicum, & \\
\hline & Ganoderma lucidum, Aspergillus sp., & \\
\hline & Rhizopus sp. & \\
\hline & Saprolegnia sp. & \\
\hline \multicolumn{3}{|c|}{ (Anti-inflammatory) } \\
\hline \multirow[t]{2}{*}{ Fruits } & $\begin{array}{l}\text { Carrageenan-induced paw oedema, Formalin- } \\
\text { induced paw oedema in albino rats. }\end{array}$ & Sikha et al. (2010). [49] \\
\hline & Carrageenan-induced acute inflammation in rats & Patil et al. (2011). [50] \\
\hline \multicolumn{3}{|c|}{ ( $\alpha$-glucosidase inhibitor) } \\
\hline \multirow[t]{2}{*}{ Seed } & Yeast and intestinal & Gowri et al. (2007). [51] \\
\hline & Glucosidase inhibition & Sulaiman and Ooi (2014).[45] \\
\hline Fruits & Glucosidase inhibition Saccharomyces cerevisiae & Ponnapalli et al., 2015. [52] \\
\hline \multicolumn{3}{|c|}{ (Analgesic) } \\
\hline Stem-bark & Albino male rats, steroid. & Deraniyagala et al., 2003[53] \\
\hline Fruits & Acetic acid-induced writhing response & Sikha et al. (2010). [49] \\
\hline (Cytotoxicity) & \multirow{2}{*}{$\begin{array}{l}\text { Preliminary bioactive substances for Cancer cells } \\
\text { proliferation. }\end{array}$} & \multirow{2}{*}{ Isaac et al., 2018[54,55] } \\
\hline Leaves, Stem-bark, Roots & & \\
\hline
\end{tabular}

Table 1: Ethno Pharmacological uses and activity of Barringtonia racemosa. 


\section{International Journal of Biochemistry \& Physiology}

\section{Material and Methods}

\section{Materials}

\section{Chemicals, Drug and Kit}

All of the analytical grade chemicals, drug and the kit were procured commercially. The Streptozotocin (STZ) (Medical Resource SDN BHD Kuching, Sarawak) and metformin hydrochloride $\left(\mathrm{C}_{4} \mathrm{H}_{11} \mathrm{~N}_{5}\right)$ was decided as a positive control of the antidiabetic drug. The testeddiabetic rats were induced by the Streptozotocin (STZ) and were operatedto measure the blood glucose level of the tested rats. All other chemicals were of analytical grade and were obtained from local companies.

\section{Experimental Design}

Albino rats were obtained from the National Center for Laboratory Animal Sciences, unimas, were injected intraperitoneal with $90 \mathrm{mg} / \mathrm{kg}$ body weight STZ dissolved in $0.1 \mathrm{M}$ citrate buffer, $\mathrm{pH} 4.5(n=42)$. Control $(n=6)$ received normal diet. The rats were maintained on a normal diet in individual cages.

\section{Animal Care}

Animal care and protocols were in accordance with and approved by the Institutional Animal Ethics Committee (IAEC). Animals were housed in individual cages in a temperature and humidity controlled room

\section{Sample Collection}

The Leaves of Barringtonia racemosa was collected from Kampong Sarawak Malaysia by the river bank and Meranek at Meranek river bank in Kota-Samarahan Sarawak. Identification of the species was made by Prof Dr. Fasihuddin Bin Badruddin Ahmad and Prof Dr zaini B Assim. The samples were air-dried, cut into pieces and ground prior to analysis. It was then deposited at Department of Botany, Faculty of Resource Science and Technology, UNIMAS.

\section{Preparation of Sample extracts}

The collected Barringtonia racemosa were cut into thin slices and then air dried under shade for seven days. The dried leaves $(2 \mathrm{~kg})$ were ground with an electric blender and sieved with $40 \mathrm{~mm}$ mesh sieve to get a fine powder. The powder was stored in a dark bottle at room temperature until use.

\section{Extraction Method}

The leaves of Barringtonia racemosa was extracted by the conventional solvent extraction method as described by Fasihuddin, et al. [56]. This was achieved by soaking the ground powdered leaves in non-polar, medium polar and polar solvents in the order of increasing polarity. A total of $2 \mathrm{~kg}$ of the dried and ground Leaves of Barringtonia racemosa was extracted using cold soaking method with hexane $\left(\mathrm{C}_{6} \mathrm{H}_{14}\right)$. The samples were soaked in the hexane with the ratio of 1:3 in 5 litres Erlenmeyer flasks at room temperature for 72 hours. The resulting hexane solution was then filtered using filter paper and the residue was re-extracted with fresh hexane for another 72 hours and filtered. All the extracts were combined and concentrated using the rotary evaporator of model Heidolph Laborota 4000 efficient, under reduced pressure to obtain the hexane crude extract. The residues were then re-extracted using the same procedure with dichloromethane $\left(\mathrm{CH}_{2} \mathrm{CL}_{12}\right)$, then ethyl acetate $\left(\mathrm{C}_{2} \mathrm{H}_{5} \mathrm{COOH}\right)$, chloroform $\left(\mathrm{CHCl}_{3}\right)$, and methanol $(\mathrm{MeOH})$ to obtain various extract of sample of dichloromethane, ethyl acetate, chloroform and methanol crude extracts, respectively.

\section{DPPH Assay}

The DPPH (2,2-diphenyl-1-picrylhydrazyl, $\mathrm{C}_{18} \mathrm{H}_{12} \mathrm{~N}_{5} \mathrm{O}_{6}$ ) as reported by Issac UJ [38] the leaves extract of Barringtonia racemosa was applied to evaluate the antioxidant activity to be $\mathrm{IC}_{50}=45.75$ which gives a base line potential of the activity of the extract against type 2 diabetic.

\section{In Vivo Experiment}

The healthy albino rats (150-200 g body weight) were conditioned in a cage for a week. After a week adaptation, the rats were separated into eight groups by setting: The Normal, negative and positive group. The remain five groups are the extract (dose) group of 100, 200, 300, 400, and $500 \mathrm{mg} / \mathrm{kg} / \mathrm{bwt}$. Individual rat in each group was collected its blood on the 7th day and marked as a pretreatment blood. The diabetic rat was generated by giving orally one $\mathrm{mL}$ of $50 \%(\mathrm{w} / \mathrm{v})$ Streptozotocin (STZ) to each rat in each group [55] on the 8th and the 11th days. After a week since the Streptozotocin (STZ) $(90 \mathrm{mg} / \mathrm{kg} / \mathrm{bwt})$ given, the blood was collected from individual rat to check the diabetic rat according to the value blood glucose level $\geq 200 \mathrm{mg} / \mathrm{dL}$ [56]. This blood was noticeable as the blood 


\section{International Journal of Biochemistry \& Physiology}

obtained before treatment. After finding out the diabetic rat, all rats were given orally: The aqueous metforminhydrochloride of $65 \mathrm{mg} / \mathrm{kg} / \mathrm{bwt}$ in Positive control group, the aqueous tested extract of 100, 200, 300,400 and $500 \mathrm{mg} / \mathrm{kg} / \mathrm{bwt}$ in the extracts treatment group respectively every day after $24 \mathrm{hrs}$ for 21 days.

Later on this point, the individual rat in each group was collected its blood. The blood was noticeable as the blood obtained after treatment. One day later, a rat in each group was selected to be sacrificed for histopathological observation on the kidney and pancreas organs. The difference of blood glucose level was stated as an antidiabetic effect.

\section{Histopathological Study}

The kidney and pancreas organs were submerged in Neutral Buffered Formalin for a week and then histopathological investigations were performed [57]. The slices were stained with Haematoxylin Eosin (HE) and studied under Olympus binocular research microscope.

\begin{tabular}{|c|c|c|c|c|}
\hline \multicolumn{7}{|c|}{ (Mean \pm SD mg/d) Blood glucose level pre-treatment (Days) } \\
\hline Treatment groups & Dose $\mathbf{~ m g} / \mathbf{k g}$ & Before experiment & 3 Pre-treatment & 7pre-treatments \\
\hline 1. Normal & $0.25 \mathrm{ml}$ & $131.3 \pm 11.3$ & $132.5 \pm 6.41$ & $132.6 \pm 6.43$ \\
\hline 2. Negative & $90 \mathrm{mg} / \mathrm{kg} / \mathrm{bwt}$ & $414.3 \pm 13.5$ & $414.5 \pm 5.32$ & $415.7 \pm 5.41$ \\
\hline 3. Positive & $65 \mathrm{mg} / \mathrm{kg} / \mathrm{bwt}$ & $428.4 \pm 4.5$ & $428.5 \pm 45.5$ & $428.5 \pm 3.62$ \\
\hline 4. Extracts & $100 \mathrm{mg} / \mathrm{kg} / \mathrm{bwt}$ & $415.3 \pm 12.3$ & $417 \pm 5.35^{*}$ & $418.7 \pm 52.42^{\mathrm{d}}$ \\
\hline 5. Extracts & $200 \mathrm{mg} / \mathrm{kg} / \mathrm{bwt}$ & $435.6 \pm 13.5$ & $437.7 \pm 7.7$ & $438.5 \pm 6.71$ \\
\hline 6. Extracts & $300 \mathrm{mg} / \mathrm{kg} / \mathrm{bwt}$ & $425.3 \pm 2.8$ & $427.3 \pm 5.9^{*}$ & $435.9 \pm 7.62$ \\
\hline 7. Extracts & $400 \mathrm{mg} / \mathrm{kg} / \mathrm{bwt}$ & $457.6 \pm 6$. & $457.9 \pm 1.3$ & $458.2 \pm 4.31^{\mathrm{d}}$ \\
\hline 8. Extracts & $500 \mathrm{mg} / \mathrm{kg} / \mathrm{bwt}$ & $418.6 \pm 32.5^{*}$ & $433.4 \pm 3.5^{*}$ & $434.3 \pm 3.92^{\mathrm{c}}$ \\
\hline
\end{tabular}

Table 2: Effect of Barringtonia racemosa Dichloromethane extracts on Mean Streptozotocin (STZ) of type 2 Diabetic Rats.

Value with superscripts $c$ with a group along the row is significantly $(\mathrm{P}<0.05)$ higher than zero hours' blood glucose value with superscript $d$ within the group along the row are significantly $(\mathrm{P}<0.05)$ lower than zero hours' blood glucose value. While value with superscript * between groups along the column is significantly $(\mathrm{P}<0.05)$ lower than blood glucose value in the diabetic control.

\begin{tabular}{|c|c|c|c|c|c|c|c|}
\hline \multicolumn{7}{|c|}{ (Mean \pm SD $\mathbf{~ m g / d l ) ~ B l o o d ~ g l u c o s e ~ l e v e l ~ p o s t ~ t r e a t m e n t ~ ( D a y s ) ~}$} \\
\hline Treatment groups & Dose $\mathbf{~ m g / k g / b w t ~}$ & $\mathbf{0}$ & $\mathbf{3}$ & $\mathbf{7}$ & $\mathbf{1 4}$ & $\mathbf{2 1}$ & $\mathbf{2 8}$ \\
\hline 1. Normal & $0.25 \mathrm{ml}$ & $132.6 \pm 6.43$ & $123.5 \pm 6.4^{*}$ & $411.7 \pm 5.4 \mathrm{a}^{*}$ & $119.4 \pm 7.3^{*}$ & $120.0 \pm 5.5^{*}$ & $121.2 \pm 4.4 \mathrm{~b}^{*}$ \\
\hline 2. Negative & $90 \mathrm{mg} / \mathrm{kg} / \mathrm{bwt}$ & $415.7 \pm 5.14$ & $388.5 \pm 5.3 \mathrm{a}^{*}$ & $122.6 \pm 6.4^{*}$ & $417.7 \pm 5.9 \mathrm{a}$ & $427.2 \pm 8.6 \mathrm{~b}^{*}$ & $456.7 \pm 6.4 \mathrm{a}$ \\
\hline 3. Positive & $65 \mathrm{mg} / \mathrm{kg} / \mathrm{bwt}$ & $428.5 \pm 3.62$ & $243.5 \pm 45.5$ & $222.5 \pm 3.6^{*}$ & $199.3 \pm 3.4 \mathrm{c}^{*}$ & $176.3 \pm 6.4$ & $166.6 \pm 5.2 \mathrm{a}^{*}$ \\
\hline 4. Extracts & 100 & $418.7 \pm 52.42$ & $326.4 \pm 5.3^{*}$ & $298.7 \pm 52.4 \mathrm{a}^{*}$ & $232.78 \pm 15.3$ & $224.6 \pm 11.8$ & $217.7 \pm 9.7$ \\
\hline 5. Extracts & 200 & $438.5 \pm 6.71$ & $327.7 \pm 7.7 \mathrm{c}^{*}$ & $311.5 \pm 6.7 \mathrm{a}^{*}$ & $255.5 \pm 4.4$ & $233.3 \pm 4.5$ & $115.2 \pm 8.5 \mathrm{~b}$ \\
\hline 6. Extracts & 300 & $435.9 \pm 7.62$ & $287.3 \pm 5.9 \mathrm{c}^{*}$ & $235.9 \pm 7.6 \mathrm{a}^{*}$ & $218.7 \pm 7.4$ & $205.8 \pm 3.7$ & $176.9 \pm 6.4^{*}$ \\
\hline 7. Extracts & 400 & $458.2 \pm 4.31$ & $277.9 \pm 1.3$ & $201.8 \pm 4.3$ & $195.3 \pm 7.3^{*}$ & $182.4 \pm 2.2$ & $152.8 \pm 3.6^{*}$ \\
\hline 8. Extracts & 500 & $434.6 \pm 3.29$ & $233.4 \pm 3.5$ & $190.8 \pm 3.9$ & $175.3 \pm 2.7 *$ & $153.4 \pm 5.5^{*}$ & $95.5 \pm 5.8^{*}$ \\
\hline
\end{tabular}

Table 3: Effect of Barringtonia racemosa dichloromethane extracts on blood glucose level of Streptozotocin (STZ)-induced diabetic Rats.

Value with superscripts (a) with a group along the row is significantly $(\mathrm{P}<0.05)$ higher than zero hours' blood glucose value with superscript $b$ within the group along the row are significantly $(\mathrm{P}<0.05)$ lower than zero hours' blood glucose value. While value with superscript * between groups along the column is significantly $(\mathrm{P}<0.05)$ lower than blood glucose value in the diabetic control group. 


\section{International Journal of Biochemistry \& Physiology}

\begin{tabular}{|c|c|c|}
\hline Group & Dose $\mathbf{~ m g} / \mathbf{k g} / \mathbf{b w t}$ & Proximate convolution tubule score (Mean $\mathbf{+ S D}$ ) \\
\hline 1. Normal & - & - \\
\hline 2. Negative & $90 \mathrm{mg} / \mathrm{kg} / \mathrm{bwt}$ & $0.23 \pm 1.05$ \\
\hline 3. Positive & $65 \mathrm{mg} / \mathrm{kg} / \mathrm{bwt}$ & $0.45 \pm 0.63$ \\
\hline 4. extract & 100 & $0.35 \pm 0.60$ \\
\hline 5. extract & 200 & $0.32 \pm 0.63$ \\
\hline 6. Extract & 300 & $0.34 \pm 0.61$ \\
\hline 7. Extract & 400 & $0.33 \pm 0.59$ \\
\hline 8. Extract & 500 & $0.32 \pm 0.62$ \\
\hline
\end{tabular}

Table 4: Proximate renal tubule cell score in the rats at various treatments.

$P=(0.001)$ in proximal renal tubule cell count among the treatments based on one-way ANOVA analysis. Significant statistical difference.

\begin{tabular}{|c|c|c|}
\hline Group & Dose $\mathbf{~ m g} / \mathbf{k g} / \mathbf{b w t}$ & Pancreatic $\boldsymbol{\beta}$-cell (Mean $\mathbf{+ S D}$ ) \\
\hline 1. Normal & - & - \\
\hline 2. Negative & $90 \mathrm{mg} / \mathrm{kg} / \mathrm{bwt}$ & $463.20 \pm 10.73$ \\
\hline 3. Positive & $65 \mathrm{mg} / \mathrm{kg} / \mathrm{bwt}$ & $394.04 \pm 15.35$ \\
\hline 4. extract & 100 & $382.01 \pm 10.66$ \\
\hline 5. extract & 200 & $397.23 \pm 11.45$ \\
\hline 6. Extract & 300 & $432.11 \pm 13.54$ \\
\hline 7. Extract & 400 & $486.00 \pm 23.33$ \\
\hline 8. Extract & 500 & $520.31 \pm 14.64$ \\
\hline
\end{tabular}

Table 5: Granulation of pancreatic $\beta$-cell at various treatments.

$\mathrm{P}<(0.001)$ in Pancreatic cell count among the treatment is based on one-way ANOVA analysis.

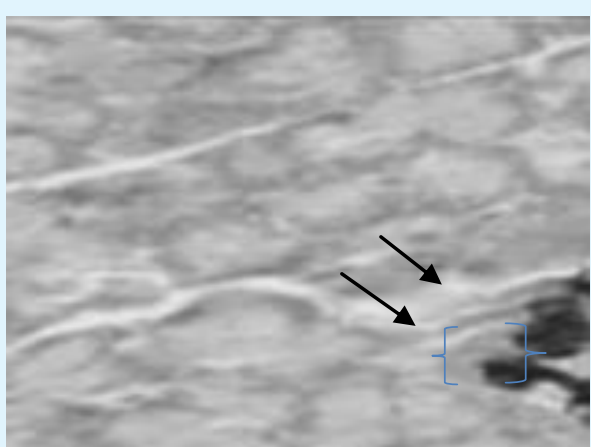

(a)

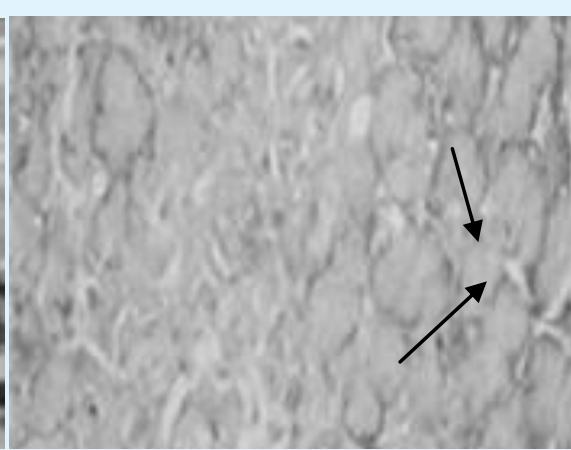

(b)

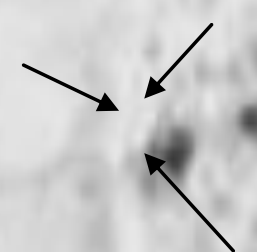

(c)

Figure 1: (b) Histopathological observation of pancreatic $\mathrm{H}$-cell as indicated by the black arrow in the normal rat, while (a). Streptozotocin (STZ) induced pancreatic $\mathrm{H}$-cell and (c). Diabetic rat + Barringtonia racemosa Dichloromethane extract with a dose of $400 \mathrm{mg} / \mathrm{kg} / \mathrm{bwt}$. 


\section{International Journal of Biochemistry \& Physiology}

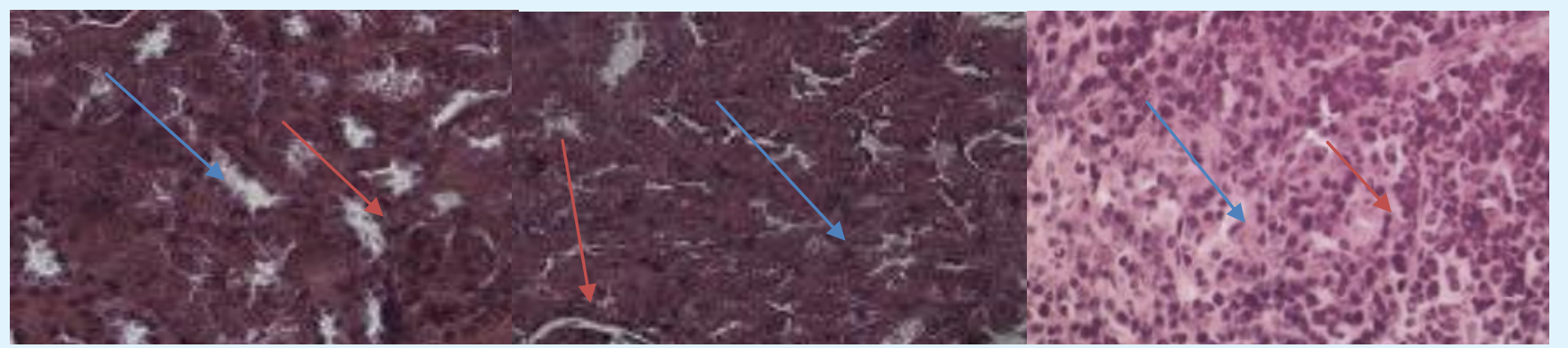

(a)

(b)

(c)

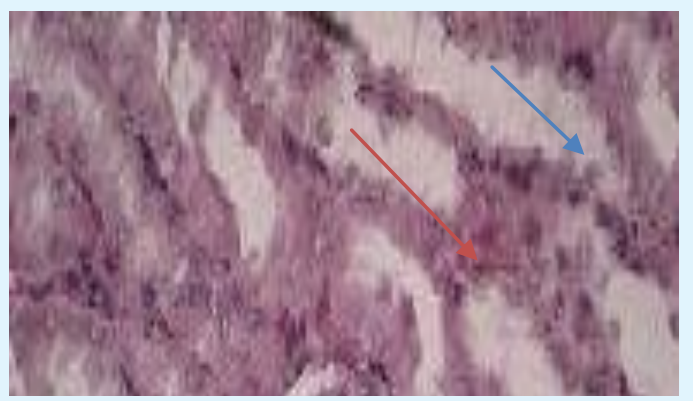

(d)

Figure 2: Histopathological performance of kidney in the normal rat (a), Metforminhydrochloride (b), diabetic rat + Dichloromethane extract with dose in $100 \mathrm{mg} \mathrm{kg}-1$ b.wt. (c), diabetic rat + Barringtonia extract with a dose of 500 $\mathrm{mg} / \mathrm{kg} / \mathrm{bwt}$. (d). Pink arrow: Proximal convoluted tubule, Blue arrow: Glomerulus.

\section{Results}

The in vivo experiment on the Streptozotocin (STZ)induced T2-diabetic rats shown decreasing the blood glucose level along with increasing dose of the extract as shown in Table 3, The study of the proximate renal tubule cell scores in the rat's kidney at various treatment indicated renal damage within the normal range and as well as increase in the $\beta$-cell granulation (Table 4 and 5).

\section{Discussion}

Type 2 Diabetes is a metabolic disorder which has genetic and lifestyle etiology. A delayed treatment that is inadequate and when administered too late it predisposes the affected individual to the complications of diabetes. However, Streptozotocin is an agent that is frequently used to induce diabetes mellitus in albino rats $[58,59]$. It is generally accepted that the cytotoxicity produced by streptozotocin affects the DNA alkylation and subsequent activation of poly (ADP-ribose) synthetase. This causes rapid and dangerous depletion of
NAD in pancreatic islets $[60,61]$. It was also reported that the free radicals may play an essential role in the mechanism of $\beta$-cell damage and effect of streptozotocin induced-diabetes [62], thus the presence of antioxidant at $36.55 \mu \mathrm{g} / \mathrm{mL}$.

The progression of T2Diabetes begins with an impairment of glucose tolerance $[63,64]$ and is often associated with a state of insulin resistance. Renal histopathologic observational data were described in semi-quantitative descriptive and scores with a scale of 0 to 2 [65]. The mark 0 states no lesions in the organ. The mark 1 suggests hydropic degeneration, fatty degeneration, karyomegaly and pycnosis. The mark 2 states the occurrence of necrosa. Each individual score was then counted up and the mean of the group was determined for comparison with controls, then, a mild (score 0 ), moderate (score 1) and severe (score 2) lesions were identified.

Table 4 presented proximate renal tubule cell score in the rats at various treatments, at $300 \mathrm{mg} / \mathrm{kg} / \mathrm{bwt}$ $0.34 \pm 0.61$ the proximate convolution tubule score was 


\section{International Journal of Biochemistry \& Physiology}

significant $(p>0.05)$ which followed by $400 \mathrm{mg} / \mathrm{kg} / \mathrm{bwt}$ with $0.33 \pm 0.59$, and $500 \mathrm{mg} / \mathrm{kg} / \mathrm{bwt}$ with $0.32 \pm 0.62$ when compared to the control

The kidney is a target organ of insulin. Insulin binds to the insulin receptors via the nephron [66], which is essential for the proper function of the nephron, glomerulus and tubule [67]. In insulin resistance, the insulin signalling cascade in the glomerulus seems to be impaired [68]. In diabetic conditions, insulin stimulation in the transportation of proximal renal tubules is impaired so that glucose reabsorption decreases and glucose is excreted through urine [67]. The administration of the Barringtonia racemosa extract improved the kidney and the visible cells in the proximal tubule was the same as absorbed in the normal rat (Figure 2).

However, plant extract as reported by Isaac, et al., is said to have antioxidant potential with $\mathrm{IC}_{50}$ value of $36.55 \mu \mathrm{g} / \mathrm{mL}$, this fact suggested the ability of the extract to reduce free radical molecule which in this case may be contributed to the potential activity of this extract against T2D, as well as some result of some bioactive compound which are also responsible for its antibacterial, antifungal, analgesic activity, such as terpenes and flavonoid which has the ability to neutralize the DPPH molecule and also the properties as a free radical and a scavenger for other free radicals [69].

The result obtained from figure 3 showed that the Dichloromethane extract of Barringtonia racemosa given to the diabetic rats did not cause any significant change in the histologic structure of the kidney. Thus, agreed with [70]. This suggested that administration of the Barringtonia racemosa dichloromethane Leave extract in diabetic rats did not show specific damage to proximal renal tubular cells either. Thus, the bioactive compound contained in the extract did not cause damage to the kidney organs in the tested rats when compared to the controlling agent for type 2 diabetes.

However, the histopathologic images demonstrated that the pancreatic $\beta$-cell granulation was directly proportional to the given extract dose as shown in Table 5 . The granulation of pancreatic $\beta$-cell at various treatments showed a remarkable significant result with increase in the concentration of the extract when compared to the control with $394.04 \pm 15.35$ and $382.01 \pm 10.66$ at $100 \mathrm{mg} / \mathrm{kg} / \mathrm{bwt}, \quad 397.23 \pm 11.45$ at $200 \mathrm{mg} / \mathrm{kg} / \mathrm{bwt}, 432.11 \pm 13.54$ at $300 \mathrm{mg} / \mathrm{kg} / \mathrm{bwt}$ as well as $400 \mathrm{mg} / \mathrm{kg} / \mathrm{bwt}$ and $500 \mathrm{mg} / \mathrm{kg} / \mathrm{bwt}$ with increase in the $486.00 \pm 23.33$ and $520.31 \pm 14.64$ respectively.

The number of $\beta$-cells enhancement is significant with $\mathrm{p}<0.05$ ) for each treatment stated that the dichloromethane extract administered to hyperglycaemic rats, which invariably improve pancreatic $\beta$-cells and depresses necrosis or apoptosis of pancreatic $\beta$-cells when compared to metformin hydrochloride as shown in Figure 2. It was assumed that the modulatory effects of Barringtonia racemosa crude extract constituents on the blood glucose transporter by increasing insulin secretion, decreasing apoptosis and stimulating proliferation of pancreatic $\beta$-cells which agrees with the report of Zheng [71].

\section{Conclusion}

The bound flavonoids and some other bioactive component of Barringtonia racemosa leafs extractshowed the strong antioxidant power and it displayed the type 2 anti-diabetes property. Administration of the extract with doses of $100 \mathrm{mg} / \mathrm{kg} / \mathrm{bwt}$. and $200 \mathrm{mg} / \mathrm{kg} / \mathrm{bwt}$. orally for 14 days was not causing the histopathologic disturbance on the tested rat kidney organ. Thus this plant extract should be used as an agent for type 2 diabetics.

\section{Acknowledgement}

The author Isaac John Umaru wish to appreciate Federal University of Wukari for Grant Fellowship and Universiti Malaysia Sarawak Natural Product Laboratory for their support.

\section{Conflict of Interest}

The authors declare that they do not have any conflict of interests.

\section{Author's Contribution}

Isaac John Umaru: Conceived, designed, performed the experiments and wrote the paper.

Hauwa A. Umaru: Provided reagents, data analyses and experimental tools analyses

Kerenhappuch I. Umaru: Materials and analysed the data.

\section{Ethics}

This original article contains unpublished material. The corresponding author states that all of the other
Umaru IJ, et al. Assessment of Type 2 Anti-Diabetes on Barringtonia racemosa (L.) Dichloromethane Extract in Streptozotocin (STZ) - Induced Diabetic Rats. Int J Biochem Physiol 2018, 3(5): 000141.
Copyright@ Umaru IJ, et al. 


\section{International Journal of Biochemistry \& Physiology}

authors have read and agreed to the manuscript and no ethical issues are involved.

\section{References}

1. Bastaki S (2005) Diabetes mellitus and its treatment. Int J Diabetes Metab 13: 111-134.

2. Leahy JL, Hirsch IB, Peterson KA, Schneider D (2010) Targeting beta-cell function early in the course of therapy for type 2 diabetes mellitus. J Clin Endocrinol Metab 95(9): 4206-4216.

3. Rains JL, Jain SK (2011) Oxidative stress, insulin signalling and diabetes. Free Radical Biol Med 50: 567-575.

4. Maritim AC, Sanders RA, Watkins JB (2003) Diabetes, oxidative stress, and antioxidants: a review. J Biochem Mol Toxicol 17(1): 24-38.

5. Suryanarayana P, Saraswat M, Mrudula T, Krishna TP, Krishnaswamy K (2005) Curcumin and turmeric delay streptozotocin-induced diabetic cataract in rats. Invest Ophthalmol Vis Sci 46(6): 2092-2099.

6. Suryanarayana P, Saraswat M, Petrash JM, Reddy GB (2007) Emblica officinalis and its enriched tannoids delay streptozotocin-induced diabetic cataract in rats. Mol Vis 13: 1291-1297.

7. Suryanarayana P, Satyanarayana A, Balakrishna N, Kumar PU, Reddy GB (2007) Effect of turmeric and curcumin on oxidative stress and antioxidant enzymes in streptozotocin-induced diabetic rat. Med Sci Monit 13(12): BR286-BR292.

8. World Health Organization (2011) Diabetes: Key Facts, World Health Organization, Geneva, Switzerland.

9. Shaw JE, Sicree RA, Zimmet PZ (2010) Global estimates of the prevalence of diabetes for 2010 and 2030. Diabetes Res Clin Pract 87(1): 4-14.

10. Zhang S, Chai FY, Yan H, Guo Y, Harding JJ (2008) Effects of N-acetylcysteine and glutathione ethyl ester drops on streptozotocin-induced diabetic cataract in rats. Mol Vis 14: 862-870.

11. Drel VR, Xu W, Zhang J, Pavlov IA, Shevalye H, et al. (2009) Poly (adenosine 5'-diphosphate-ribose) polymerase inhibition counteracts multiple manifestations of experimental type 1 diabetic nephropathy. Endocrinology 150(12): 5273-5283.

12. Siddiqui TA, Shadab Z, Nishat I, Ayasha N, Zehra Z, et al. (2003) Anticataract activity of Kohl-Chikni Dawaa compound ophthalmic formulation of Unani medicine in alloxan-diabetic rats. J Ethnopharmacol 86(1): 109-12.

13. Vats V, Yadav SP, Grover JK (2004) Ethanolic extract of Ocimum sanctum leaves partially attenuates streptozotocin-induced alterations in glycogen content and carbohydrate metabolism in rats. J ethnopharmacol 90(1): 155-160.

14. Preet A, Gupta BL, Siddiqui MR, Yadava PK, Baquer NZ (2005) Restoration of ultrastructural and biochemical changes in alloxan-induced diabetic rat sciatic nerve on treatment with $\mathrm{Na} 3 \mathrm{VO} 4$ and Trigonella-a promising antidiabetic agent. Mol Cell Biochem 278(1-2), 21-31.

15. Saraswat M, Suryanarayana P, Reddy PY, Patil MA, Balakrishna N, et al. (2010) Antiglycating potential of Zingiber officinalis and delay of diabetic cataract in rats. Mol Vis 16: 1525.

16. Schaffer SW, Wilson GL (1993) Insulin resistance and mechanical dysfunction in hearts of Wistar rats with streptozotocin-induced non-insulin-dependent diabetes mellitus. Diabetologia 36(3): 195-199.

17. Takada J, Machado MA, Peres SB, Brito LC, BorgesSilva CN, et al. (2007) Neonatal streptozotocininduced diabetes mellitus: a model of insulin resistance associated with loss of adipose mass. Metabolism 56(7): 977-984.

18. Anwer T, Sharma M, Pillai KK, Iqbal M (2008) Effect of Withania somnifera on Insulin Sensitivity in Non-Insulin-Dependent Diabetes Mellitus Rats. Basic Clin Pharmacol Toxicol 102(6): 498-503.

19. Abdollahi M, Zuki AB, Goh YM, Rezaeizadeh A, Noordin MM (2011) Effects of Momordica charantia on pancreatic histopathological changes associated with streptozotocin-induced diabetes in neonatal rats. Histol Histopathol 26(1): 13-21.

20. Movassat J, Portha B (2007) Early administration of keratinocyte growth factor improves $\beta$-cell regeneration in rat with streptozotocin-induced diabetes. J Endocrinol 195(2): 333-340. 


\section{International Journal of Biochemistry \& Physiology}

21. Portha B, Levacher C, Picon L, Rosselin G (1974) Diabetogenic effect of streptozotocin in the rat during the perinatal period. Diabetes 23(11): 889-895.

22. Weir GC, Clore ET, Zmachinski CJ, Bonner-Weir S (1981) Islet secretion in a new experimental model for non-insulin-dependent diabetes. Diabetes 30(7): 590-595.

23. Iwase M, Kikuchi M, Nunoi K, Wakisaka M, Maki Y, et al. (1986) A new model of type 2 (non-insulindependent) diabetes mellitus in spontaneously hypertensive rats: diabetes induced by neonatal streptozotocin treatment. Diabetologia 29(11): 808811.

24. Grill V, Westberg M, Ostenson CG (1987) B cell insensitivity in a rat model of non-insulin-dependent diabetes. Evidence for a rapidly reversible effect of previous hyperglycemia. J Clin Invest 80(3): 664-669.

25. Welsh N, Hellerström C (1990) In vitro restoration of insulin production in islets from adult rats treated neonatally with streptozotocin. Endocrinology 126(4): 1842-1848.

26. Hemmings SJ, Spafford D (2000) Neonatal STZ model of type II diabetes mellitus in the Fischer 344 rat: characteristics and assessment of the status of the hepatic adrenergic receptors. Int J Biochem Cell Biol 32(8): 905-919.

27. Farswan M, Mazumder PM, Percha V. (2009) Protective effect of Cassia glauca Linn. on the serum glucose and hepatic enzymes level in streptozotocin induced NIDDM in rats. Indian J pharmacol 41(1): 1922.

28. Kim JO, Lee GD, Kwon JH, Kim KS (2009) Anti-diabetic effects of new herbal formula in neonatally streptozotocin-induced diabetic rats. Biol Pharm Bull 32(3): 421-426.

29. PariL, Ashokkumar N (2005) Effect of $\mathrm{N}$-benzoyl-d-phenylalanine on lipid profile in liver of neonatal streptozotocin diabetic rats. Fundam Clin Pharmacol. 19(5): 563-568.

30. Suryanarayana P, Krishnaswamy K, Reddy GB (2003) Effect of curcumin on galactose-induced cataractogenesis in rats. Mol Vis 9(9): 223-230.
31. Song $\mathrm{P}, \mathrm{Wu} \mathrm{Y}, \mathrm{Xu} \mathrm{J}$, Xie Z, Dong Y, et al. (2007) Reactive nitrogen species induced by hyperglycemia suppresses Akt signaling and triggers apoptosis by upregulating phosphatase PTEN (phosphatase and tensin homologue deleted on chromosome 10) in an LKB1-dependent manner. Circulation 116(14): 15851595.

32. Zimmet P, Thomas CR (2003) Genotype, obesity and cardiovascular disease-has technical and social advancement outstripped evolution? Journal of internal medicine 254(2): 114-125.

33. Khan S, Jabbar A, Hasan CM, Rashid MA (2001) Antibacterial activity of Barringtonia racemosa. Fitoterapia 72(2): 162-164.

34. Thomas TJ, Panikkar B, Subramoniam A, Nair MK, Panikkar KR (2002) Antitumour property and toxicity of Barringtonia racemosa Roxb seed extract in mice. J Ethnopharmacol 82(2-3): 223-227.

35. Kabir MZ, Rahman SM, Islam MR, Paul PK, Rahman S (2013) A review on a mangrove species from the Sundarbans, Bangladesh: Barringtonia racemosa (L.) roxb. Am Eurasian J Sustainable Agric 7: 356-372.

36. Osman NI., Sidik NJ, Awal A (2015) Pharmacological activities of Barringtonia racemosa L. (Putat), a tropical medicinal plant species. J Pharm Sci Res 7: 185-188.

37. Lim TK (2012) Barringtonia racemosa. In: Edible Medicinal and Non-Medicinal Plants, Lim TK (Ed.), Springer Science and Business Media BV, Dordrecht, Heidelberg, London and New York, pp: 114-121.

38. Umaru IJ, Ahmed FB, Umaru HA, Umaru KI (2018) Barringtonia racemosa: phytochemical, pharmacological, biotechnological, botanical, traditional use and agronomical aspects. World Journal of Pharmacy and Pharmaceutical Sciences $7(8): 78-121$.

39. Giesen W, Wulfraat S, Zieren M, Scholten L(2007) Barringtonia Racemosa. In: Mangrove Guidebook for Southeast Asia, FAO and Wetlands International, Bangkok, Thailand and Wageningen, Netherlands.

40. Manjunath BL (1948) The Wealth of India: A Dictionary of Indian Raw Materials and Industrial Products. 1st Edn., Council of Scientific and Industrial Research, New Delhi, pp: 159. 


\section{International Journal of Biochemistry \& Physiology}

41. Jayaweera DMA (1981) Medicinal plants (indigenous and exotic) used in Ceylon, part III. The National Science Council of Sri Lanka, Colombo.

42. Nadkarni AK (1976) Dr. KM Nadakarni's Indian Materia Medica. 3rd Ed., Popular Prakashan Ltd., Bombay, pp: 177.

43. Behbahani M, Ali AM, Muse R, Mohammad NB (2007) Anti-oxidant and anti-inflammatory activities of leaves of Barringtonia racemosa. J Med Plants Res 1: 95-102.

44. Kong KW, Mat-Junit S, Ismail A, Aminudin N, AbdulAziz A (2014) Polyphenols in Barringtonia racemosa and their protection against oxidation of LDL, serum and haemoglobin. Food Chem 146: 85-93.

45. Sulaiman SF, Ooi kKL (2014) Antioxidant and $\alpha$ glucosidase inhibitory activities of 40 tropical juices from Malaysia and identification of phenolics from the bioactive fruit juices of Barringtonia racemosa and Phyllanthus acidus. J Agric Food Chem 62(39): 9576-9585.

46. Mmushi T, Masoko P, Mdee L, Mokgotho M, Mampuru LJ, et al. (2010) Anti-mycobacterial evaluation of fifteen medicinal plants in South Africa. Afr J Tradit Complement Altern Med 7(1): 34-39.

47. Saha S, Sarkar KK, Hossain ML, Hossin A, Barman AK, et al. (2013) Bioactivity studies on Barringtonia racemosa (lam.) Bark. Pharmacol.m OnLine 1: 93100.

48. Hussin NM, Muse R, Ahmad S, Ramli j, Mahmood M, et al. (2009) Antifungal activity of extracts and phenolic compounds from Barringtonia racemosa $\mathrm{L}$. (Lecythidaceae). Afr J Biotechnol 8(12): 2835-2842.

49. Sikha P, Latha PG, Suja SR, Anuja GI, Shyamal S, et al. (2010) Anti-inflammatory and analgesic activity of Barringtonia racemosa Roxb. Fruits. Ind J Nat Prod Resour 1(3): 356-361.

50. Patil KR, Patil CR, Jadhav RB, Mahajan VK, Raosaheb P (2011) Anti-arthritic activity of bartogenic acid isolated from fruits of Barringtonia racemosa Roxb. (Lecythidaceae). Evidence-Based Complementary Alternative Med 2011: 1-7.

51. Gowri PM, Tiwari AK, Ali AZ, Rao JM (2007) Inhibition of $\alpha$-glucosidase and amylase by bartogenic acid isolated from Barringtonia racemosa Robx. seeds. Phytotherapy Res 21: 796-799.

52. Ponnapalli MG, Sukki S, Annam SCVAR, Ankireddy M, Tirunagari $\mathrm{H}$, et al. (2015) $\alpha$-Glucosidase inhibitory monoacylated polyhydroxytriterpenoids from the fruits of Barringtonia racemosa. Tetrahedron Lett 56: 1570-1574.

53. Deraniyagala SA, Ratnasooriya WD, Goonasekara CL (2003) Antinociceptive effect and toxicological study of the aqueous bark extract of Barringtonia racemosa on rats. J Ethnopharmacol 86(1): 21-26.

54. ADA (2015) Classification and diagnosis of diabetes. Diabetes Care 38: 58-516

55. Umaru IJ, Badruddin FA, Assim ZB, Umaru HA (2018) Cytotoxicity (Brine shrimp Lethality Bioassay) of Barringtonia racemosa Leaves, Stem-Bark and Root Extract. Journal of Biotechnology and Bioengineering, 2(2): 45-50.

56. Fasihuddin BA, Sallehuddin NKNM, Assim Z (2010) Chemical constituents and antiviral study of Goniothalamus velutinus. Malaysian Journal of Fundamental and Applied Sciences 6(1): 73-76.

57. Arul B, Kothai R, Christina AJM (2006) Antihyperglycemic and hypoglycemic effect of Bougainvillea spectabilis Linn. In normal and glucoseinduced diabetic rats. Hamdard Med 49: 1821.

58. Candasamy M, Murthy TE, Gubiyappa KS, Chellappan DK, Gupta G (2014) Alteration of glucose lowering effect of glibenclamide on single and multiple treatments with fenofibrate in experimental rats and rabbit models. J Basic Clin Pharmacy 5(3): 62-67.

59. Spitalnik PF (2016) Histology laboratory manual 2016-2017. College of Physicians and Surgeons, Columbia University, New York.

60. Szkudelski T (2001) The mechanism of alloxan and streptozotocin action in $\beta$-cells of the rat pancreas. Physiol Res 50(6): 537-46.

61. Yamagishi N, Nakayama K, Wakatsuki T, Hatayama T (2001) Characteristic changes of stress protein expression in streptozotocin induced diabetic rats. Life Sci 9(22): 2603-2609. 


\section{International Journal of Biochemistry \& Physiology}

62. Bennet RA, Pegg AE (1981) Alkylation of DNA in rat tissues following administration of streptozotocin. Cancer Res 41(7): 2786-90.

63. Bolzan AD, Bianchi Ms (2002) Genotoxicity of streptozotocin. Mutat Res 512(2-3): 121-134.

64. Ohkuwa T, Sato Y, Naoi M (1995) Hydroxyl radical formation in diabetic rat induced by streptozotocin. Life Sci 56(21): 1789-1798.

65. Suhita NLPR, Sudira IW, Winaya IBO (2013) Histopathological kidney of rat white the effect of the pegagan (Centella asiatica) extract against peroral. Buletin Veteriner Udayana 5(2): 71-78.

66. Nakamura R, Emmanouel DS, Katz AI (1983) Insulin binding sites in various segments of the rabbit nephron. J Clin Invest 72(1): 388-392.

67. Hale LJ, Coward RJ (2013) The insulin receptor and the kidney. Curr Opin Nephrol Hypertens 22(1): 100106.
68. Lay A, Coward RJ (2014) Recent advances in our understanding of insulin signalling to the podocyte. Nephrol Dial Transplant 29(6): 1127-1133.

69. Horita S, Nakamura M, Suzuki M, Satoh N, Suzuki A, et al. (2017) The role of renal proximal tubule transport in the regulation of blood pressure. Kidney Res Clin Pract 36(1): 12-21.

70. Khoshnoud S, Mohseni Kouchesfahani H, Nabiuni M (2017) Evaluation of the protective effect of hydroalcoholic extract of raspberry fruit on aquaporin1 expression in rats' kidney treated by methotrexate. Cell J 19(2): 306-313.

71. Zheng S, Zhao M, Wu Y, Wang Z, Ren Y (2016) Suppression of pancreatic beta cell apoptosis by Danzhi Jiangtang capsule contributes to the attenuation of type 1 diabetes in rats. BMC Complement Altern Med 16: 31-41.

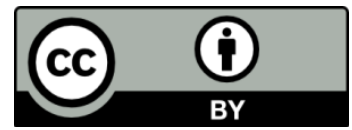

Umaru IJ, et al. Assessment of Type 2 Anti-Diabetes on Barringtonia racemosa (L.) Dichloromethane Extract in Streptozotocin (STZ) - Induced Copyright(C) Umaru IJ, et al. Diabetic Rats. Int J Biochem Physiol 2018, 3(5): 000141. 